\title{
Steps Towards Carbon Market in Russia
}

\author{
Irina Belik \\ Department of economic security of production systems \\ Ural Federal University \\ Ekaterinburg, Russia \\ Irinabelik2010@mail.ru
}

\author{
Natalia Starodubets \\ Department of economic security of production systems \\ Ural Federal University \\ Ekaterinburg, Russia \\ n.v.starodubets@gmail.com
}

\author{
Alena Yachmeneva \\ Department of economic security of production systems \\ Ural Federal University \\ Ekaterinburg, Russia
}

\begin{abstract}
The paper is dedicated to the issue of carbon market organization in Russia, which is especially important because of establishment in Russia goals for reducing greenhouse gas emissions and the intention to accede to the Paris Agreement on Climate Change. In paper authors review the situation with carbon markets in the world. Based on other countries experience, authors offer concrete, practical steps to Russian carbon market organization. Finally, authors provide an overview of the current situation with carbon market in Russia.
\end{abstract}

Keywords-The Paris Agreement on Climate Change; caborn market; greenhouse gases emissions tradyng system; in-country carbon market organization

\section{INTRODUCTION}

Today about 100 countries, including China, the US, Germany, France, Brazil, India, South Africa, Belarus, Kazakhstan, Saudi Arabia, Canada, and many others, which accounted for $70 \%$ of global greenhouse gas emissions, have ratified the Paris climate agreement and it came into force. This agreement came to replace the Kyoto Protocol to the UNFCCC, which expires in 2020 .

Paris Agreement stipulates obligations of the parties - the quantitative reduction of emissions that each party determines to achieve global temperature goals. In Russian Federation today the target is by 2020 to reduce greenhouse gases emissions to a level of no more than 75 per cent of these emissions in 1990, and by 2030 - no more than 75- 70 per cent.

It is believed that one of the most efficient ways of meeting environmental goals in GHG emissions reduction is creation of regulatory market based on cap-and-trade system.

\section{The Role of CARbon MARKetS}

This idea of carbon markets was developed in journal contributions by $[1,2,3]$. To a large extent, it was used in the flexibility mechanisms of the Kyoto Protocol and trigged the introduction of the international carbon market.

This can be explained by the fact that this mechanism is systemic, i.e., it forms a self-regulating market system characterized by dynamism, transparency, centralized coordination, the presence of established links between its elements, and, most importantly, freely tradable good (allowances). This determines its effectiveness in meeting the goals for GHG emissions reduction.

The fig. 1 shows GHG emission trading systems (ETS) which are in force to date, scheduled and under consideration.

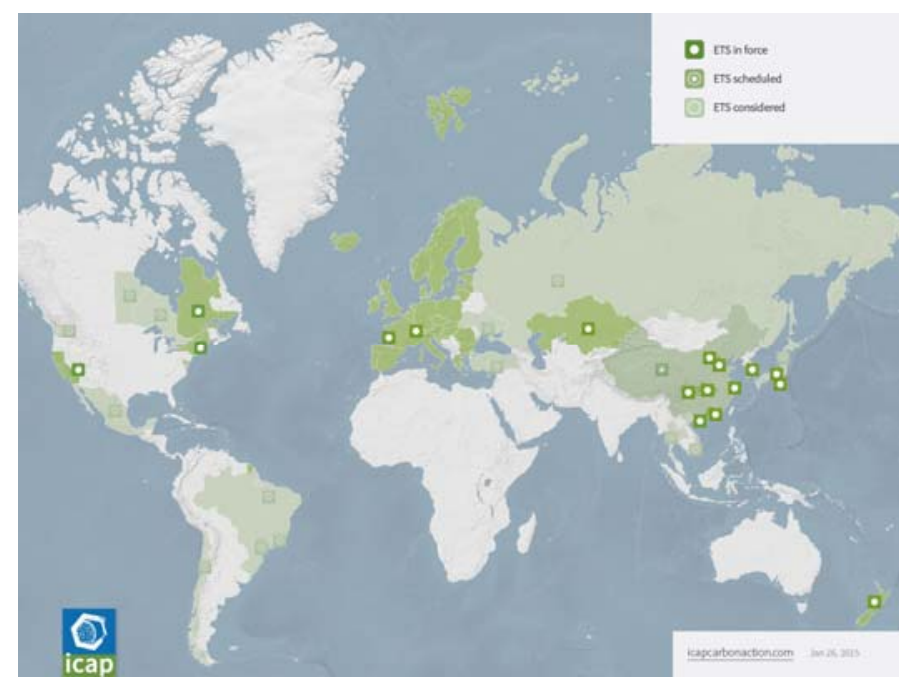

Fig. 1. World emissions trading systems (ETS) - Carbon markets (source: International Carbon Action Partnership)

Schematic diagram of GHG emissions trading is presented on fig. 2. 


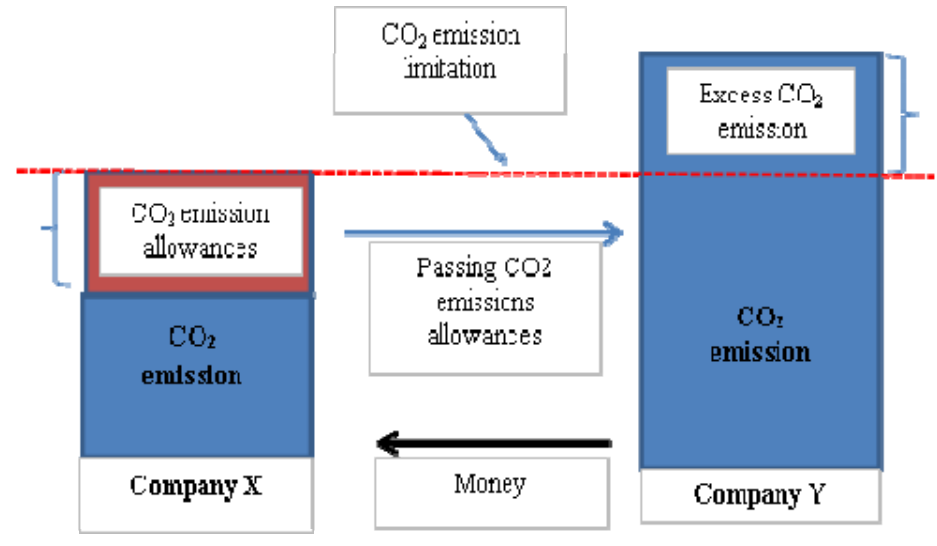

Fig. 2. Schematic diagram of GHG emissions trading

First steps towards carbon market Russia made in 2009, when the country actually started taking part in Kyoto protocol by developing all necessary legislation connected with Joined implementation (JI) projects. Many Russian companies find JI projects commercially interesting and implemented them.

According to an analytical survey made by CCGS Company (Russia) (Table 1), 156 project applications were submitted with a $\mathrm{CO}_{2}$ emission reduction potential of almost 400 million tons of $\mathrm{CO}_{2}$ equivalent till 2012.

The ERUs of 74 of the projects were sold, which means that, taking into consideration the minimum price of 5 US dollars for 1 ERU (the actual price is estimated to be higher), about 1,1 billion US dollars was raised by Russian companies implementing investment projects, most of them energy saving.

TABLE I. PARTICIPATION OF RUSSIAN COMPANIES IN JI MECHANISM OF KYOTO PROTOCOL

\begin{tabular}{|c|c|c|c|c|}
\hline \multirow[b]{2}{*}{ Types of projects } & \multicolumn{2}{|c|}{ JI projects } & \multicolumn{2}{|c|}{ ERUs sold } \\
\hline & $\begin{array}{l}\text { Number } \\
\text { of pro- } \\
\text { jects }\end{array}$ & $\begin{array}{l}\text { Ths. ton } \\
\mathrm{CO}_{2} \text { eqv } \\
\text { till } 2012 \\
\end{array}$ & $\begin{array}{c}\text { Number } \\
\text { of pro- } \\
\text { jects }\end{array}$ & $\begin{array}{l}\text { Ths. ton } \\
\mathrm{CO}_{2} \text { eqv }\end{array}$ \\
\hline $\begin{array}{l}\text { Oil industry/Oil- } \\
\text { associated gas }\end{array}$ & 36 & 153827 & 20 & 98181 \\
\hline $\begin{array}{l}\text { Energy } \\
\text { industry/Energy } \\
\text { efficiencyy }\end{array}$ & 31 & 47123 & 10 & 21223 \\
\hline $\begin{array}{l}\text { Energy } \\
\text { industry/Energy } \\
\text { efficiency }\end{array}$ & 20 & 20725 & 8 & 5127 \\
\hline $\begin{array}{l}\text { Renewables/ Bio } \\
\text { fuel }\end{array}$ & 20 & 12288 & 10 & 4367 \\
\hline Industry $/ \mathrm{CO}_{2}$ & 19 & 50327 & 13 & 29909 \\
\hline $\begin{array}{l}\text { Industry/other } \\
\text { GHG }\end{array}$ & 12 & 83006 & 8 & 70998 \\
\hline Others & 18 & 18411 & 5 & 7736 \\
\hline Total & 156 & 385711 & 74 & 237545 \\
\hline
\end{tabular}

The most ERU's were sold from projects in oil industry/oilassociated gas (41\% from all ERU's being sold) and from and projects connected with utilization of particularly harmful GHG, such as hydrofluorocarbon-23 and hexafluoride sulfur (about $30 \%$ of ERUs being sold).
We can say that JI implementation in Russia was a very positive result of Russia's participation in the Kyoto Protocol. This fact makes authors think, that Russian companies and decision makers will consider creating carbon market in Russia for the purpose of GHG emission reduction.

\section{RESUltS AND DISCUSSION}

In-country carbon market for countries with transition economy, including Russian Federation, can be introduced in several stages.

\section{A. Preparatory stage of carbon market introduction:}

- adoption of the necessary regulatory framework;

- approval by the authorized state body responsible for the functioning of the carbon market, including verification and acceptance reports from enterprises and maintaining the relevant register of $\mathrm{GHG}$ emissions;

- inventory of GHG emissions based on the IPCC methodology, the international standard ISO 14064-1: 2006 on both the regional and company level;

- all entities that consume energy resources provide reports of GHG emissions over the last three years and in the year chosen as the baseline (in Russia it is 1990) to the authorized state body, with verification being mandatory only for the largest companies emitting $1 \mathrm{mln}$. tons of $\mathrm{CO}_{2}$-eq. a year and more.

\section{B. Basic stage of carbon market introduction:}

- determination of carbon market participants and definition of the base line for each company in accordance with the possibility of system administration and country targets for GHG emission reduction;

- to get allowances for the current year, a company shall submit to the authorized state body the following documents confirmed by an independent accredited organization: a report on GHG inventory, the technical passport of the core equipment, a program of GHG emissions reduction for the last 5 years, an action plan for the implementation of projects to reduce GHG emissions in the current year;

- the authorized state body calculates quotas for the enterprise in the current year, taking into account the baseline, the country targets to reduce GHG emissions, the possibility of reducing GHG emissions due to the transition of the enterprise to the best available technology;

- all the data collected from the companies are included in a state program of GHG emissions reduction in the calendar year that should correlate with the country climate target.

After the framework for the in-country carbon market has been created, it starts functioning, and the following options are available to participating companies:

- output reduction, which is undesirable because it can be harmful to the economic health of enterprises;

- payment of fines for exceeding $\mathrm{CO}_{2}$ emissions limits; 
- access to the carbon market and purchase of carbon units from other companies at a market price;

- access to the carbon market and co-financing of projects leading to the reduction of GHG emissions of other enterprises, followed by separation of the carbon units in proportion to the volume of investment;

- implementation of projects leading to the reduction of GHG in the company independently or with the help of coother interested investors, followed by the sharing of the carbon units in proportion to the volume of investment.

The choice of a carbon strategy and a set of practical steps by a company in each individual case will be based on the criterion of achieving the desired emission reduction at a lower cost.

Today we can say that Russia is still on the preparatory stage of carbon market introduction and some actions are already taken:

-Ministry of natural resources and environment has prepared and adopted recommendations on GHG emissions inventory, based on IPCC methodology, for companies and regions;

- Seminars are organized by Ministry of natural resources and environment for regional decision makers about the methodology of regional GHG emission inventory;

- In 2015 Ministry of natural resources and environment required 85 Russian regions to carry out voluntary GHG emissions inventory-as a result, only $20 \%$ followed this recommendation, but this experience may be useful for other regions, when inventory becomes obligatory;

- in November 2016 Premier Minister of Russia enacted a law, in which a set of measures were approved, involving adjustments to the existing strategic documents and the preparation of new, defining the state policy in the field of climate change, as well as the development of the model of state regulation of greenhouse gas emissions in Russia.

\section{CONCLUSION}

All these actions taken make authors believe that Russia is on the way to the carbon market implementation and will reach the climate goal and reduce GHG emissions by $25 \%$ to 2020 from the level of 1990 and by $25 \%-30 \%$ to 2030 from the level of 1990, as it was stated in the international discussion of Paris Agreement on Climate Change.

\section{REFERENCES}

[1] Crocker, T.D. The structure of atmospheric pollution control systems. New York: W.W. Norton, 1966.J. Clerk Maxwell, A Treatise on Electricity and Magnetism, 3rd ed., vol. 2. Oxford: Clarendon, 1892, pp.68-73.

[2] Dales, John H. Pollution, Property and Prices: An Essay in Policymaking and Economics. University of Toronto Press, 1968.

[3] Montgomery, D. Markets in Licenses and Efficient Pollution Control Programs. Journal of Economic Theory. 1972, 5(3), pp. 395-418. 